\title{
Evaluation of neonatally-induced mild diabetes in rats: Maternal and fetal repercussions
}

\author{
Isabela L lessi1, Aline Bueno1, Yuri K Sinzato1, Kristin N Taylor1,2, Marilza VC Rudge1 and Débora C Damasceno*1
}

\begin{abstract}
Many experimental studies have been performed to evaluate mild diabetes effects. However, results are divergent regarding glycemia and insulin measurement, fetal macrossomia, and placental weights. The aim was to investigate repercussions of neonatally-induced mild diabetes on the maternal organism and presence of congenital defects in their offspring in other mild diabetes model. On the day of birth, female offspring were distributed into two groups: Group streptozotocin (STZ): received $100 \mathrm{mg} \mathrm{STZ/kg} \mathrm{body} \mathrm{weight,} \mathrm{and} \mathrm{Control} \mathrm{Group:} \mathrm{received} \mathrm{vehicle} \mathrm{in} \mathrm{a} \mathrm{similar} \mathrm{time}$ period. Maternal weights and glycemias were determined at days 0, 7, 14 and 21 of pregnancy. At day 21 of pregnancy, the rats were anesthetized and a laparotomy was performed to weigh and analyze living fetuses and placentas. The fetuses were classified as small (SPA), appropriate (APA) and large (LPA) for pregnancy age. Fetuses were also analyzed for the presence of external anomalies and processed for skeletal anomaly and ossification sites analysis. Statistical significance was considered as $p<0.05$. In STZ group, there was increased glycemia at 0 and 14 days of pregnancy, lower weights throughout pregnancy, higher placental weight and index, an increased proportion of fetuses classified as SPA and LPA, and their fetuses presented with an increased frequency of abnormal sternebra, and absent cervical nuclei, which were not enough to cause the emergence of skeletal anomalies. Thus, this study shows that mild diabetes altered fetal development, characterized by intrauterine growth restriction. Further, the reached glycemia does not lead to any major congenital defects in the fetuses of streptozotocin-induced mild diabetic rats.
\end{abstract}

\section{Introduction}

Diabetes mellitus (DM) is a metabolic disorder characterized by hyperglycemia, insufficient insulin secretion, and receptor insensitivity to endogenous insulin. Its incidence is associated with high morbidity and mortality rates [1]. In pregnancies complicated by diabetes, hyperglycemia and alterations in lipid metabolism are associated with both maternal and fetal complications [2,3], causing reproductive abnormalities that enhance spontaneous abortion, congenital anomalies, and neonatal morbidity and mortality $[4,5]$.

Congenital anomalies are more common in infants of diabetic women than in children of nondiabetic women. The etiology, pathogenesis and prevention of diabetesinduced anomalies have spurred considerable clinical and basic research efforts. The infant of the diabetic mother also has increased risk for several neonatal complications,

\footnotetext{
* Correspondence: damasceno@fmb.unesp.br

1 Botucatu Medical School, UNESP - Univ Estadual Paulista, Department of Gynecology and Obstetrics, Laboratory of Experimental Research in Gynecology and Obstetrics, São Paulo State, Brazil

Full list of author information is available at the end of the article
}

such as macrosomia, hypoglycemia, hypocalcemia, polycythemia and hyperbilirubinemia. Up to $25 \%$ of such offspring have been reported with these complications. It also appears that early detection and subsequent strict metabolic control of pregnant women with diabetes in pregnancy should decrease the frequency and severity of some of these short- and long-term complications in the offspring of the diabetic mother [4].

Despite increased clinical efforts to improve glycemic control during diabetic pregnancy, however, the rate of congenital malformations remains increased in studies of Diabetes mellitus (DM) of type 1 [6-9], DM type 2 [9-12], and gestational diabetes (GDM) $[10,13]$. The prevalence of major congenital malformations is approximately three to five times higher in infants of diabetic mothers [14-17] and is presently the most common cause of perinatal death among these infants $[18,19]$. Diabetes is associated with a variety of anomalies, primarily cardiovascular, neurological, and musculoskeletal [20]. The malformation considered to be most pathognomic to the infants of diabetic mothers - caudal regression syndrome or sacral 
agenesis - is claimed to be 200-400-fold more frequent [21] but is still a rare anomaly.

Studies in humans that explore the responsible mechanism for these alterations are limited not only by ethical reasons but also by the multiplicity of uncontrolled variables that may modify the intrauterine environment and cause potential effects on congenital malformations. Therefore, there is a need for appropriate animal models [22].

In order to reproduce the clinical status of uncontrolled type $1 \mathrm{DM}$, experimental models are used to obtain severe diabetes (glycemia $>300 \mathrm{mg} / \mathrm{dL}$ ) [23-25]. The complications that affect in mother and fetus that result from this model are well-known. Besides, other models were developed in laboratory animals to reproduce the clinical conditions of the DM type 2 and GDM. Similarly, the experimental model proposed is identified as mild or moderate diabetes (glycemia between 120 and $300 \mathrm{mg} /$ $\mathrm{dL}$ ). To obtain this glycemic level, several methodologies may be used, such as administration of different doses of a beta-cytotoxic agent (streptozotocin) during the period neonatal $[26,27]$ or streptozotocin injection during pregnancy [28-30]. However, many experimental studies have been performed to evaluate the effects of mild diabetes, with divergent results regarding glycemia and insulin measurement, presence of fetal macrosomia and placental weights. In our laboratory, two streptozotocin administration (day 1 of birth and at day 7 of pregnancy of Wistar rats) were performed and the results showed that this mild diabetes model led a negative impact on maternal reproductive performance and caused intrauterine growth restriction and impaired fetal development (in press). Due to negative effects of this diabetes model and controversial information of the mild diabetes effects about maternal and fetal repercussions. The present study aimed to investigate the repercussions of mild diabetes in the maternal organism and the presence of congenital defects in their offspring.

\section{Methods}

Wistar rats were obtained from São Paulo State University (Unesp), Botucatu, São Paulo State, Brazil. They were maintained in an experimental room under controlled conditions of temperature $\left(22 \pm 2^{\circ} \mathrm{C}\right)$, humidity $(50 \pm$ $10 \%$ ), and a 12 hour light/dark cycle. Protocols for animal use and procedures necessary for the experiments described here were approved through the Local Experimental Ethical Committee for Research, which assures adherence to the standards established by the Guide for the Care and Use of Laboratory Animals.

Parental non-diabetic female rats were mated with nondiabetic males to obtain newborns (NB). On day 0 of birth, female NB were distributed into two groups: diabetic group $(S T Z, n=102)$ and in the STZ group female
NB received a streptozotocin injection (STZ - Sigma Chemical Company, St. Louis, Millstone, USA) administered at a dose of $100 \mathrm{mg} / \mathrm{kg}(0.1 \mathrm{M}, \mathrm{pH} 4.5)$ subcutaneously (sc) according to modified procedures [26,27]; nondiabetic group (control, $\mathrm{n}=45$ ). In the control group, female NB received only citrate buffer administered sc. NB rats remained with their mothers until day 21 of life (weaning period). In adult life, the female rats were mated overnight with non-diabetic male rats. The morning when spermatozoa were found in the vaginal smear was designated gestational day (GD) 0 . STZ rats presenting with glycemia between 120 and $300 \mathrm{mg} / \mathrm{dL}$ at GD 0 were characterized as having mild diabetes, and non-diabetic rats with glycemia below $119 \mathrm{mg} / \mathrm{dL}$ were considered control and were included in this study. On days $0,7,14$ and 21 of pregnancy, maternal body weights and glycemia were determined. Blood glucose concentrations were measured by a One-Touch Ultra glucometer (LifeScan, Johnson and Johnson ${ }^{\circ}$ ). Values were expressed in $\mathrm{mg} / \mathrm{dL}$.

On day 21 of pregnancy, fed rats were anesthetized with sodium thiopental $(50 \mathrm{mg} / \mathrm{kg})$. Following trichotomy of the abdominal region, the animal was placed in the dorsal decubitus position, and its libs were fixed to the surgery table. The laparoscopy procedure was carried out by a midline incision beginning at the xiphoid cartilage and ending at the pubis. The intestinal loops were moved cranially for uterus exposure. Immediately following exploratory laparotomy, all viable fetuses and placentas were weighed for determination of placental index (placental weight/fetal weight). The fetuses were classified by the mean $\pm 1.7 \mathrm{SD}$ according to the mean values of fetal weights of the control group: as small for pregnancy age (SPA) when weight was smaller than control mean - 1.7 SD; appropriate for pregnancy age (APA) when weight was included in control mean $\pm 1.7 \mathrm{SD}$; and large for pregnancy age (LPA) when weight was greater than control mean $+1.7 \mathrm{SD}$, and the data were presented as percentual values [3,31]. The fetuses were externally evaluated by microscope with respect to the incidence of external anomalies. After external analysis, half of the fetuses were prepared for skeletal examination by the staining procedure of Staples \& Schnell [32]. In addition to the skeletal analyses, the counting of the ossification sites was performed according to methodology proposed by Aliverti [33], which determines the degree of fetal development. The remaining fetuses were prepared for visceral examination into another study in our laboratory (data not published).

The results were reported as mean \pm standard error (SEM) or standard deviation (SD) of mean. All data were statistically analyzed using Student-Newman-Keuls test [34]. For fetal weight classification, the Chi-square test was used [35]. Statistical significance was considered as p $<0.05$. 


\section{Results}

In the present study, 102 female rats had diabetes induced by STZ at the neonatal period. Of these, 82 rats reached adult life and were mated, and 76 of these presented with a positive vaginal smear. On GD 0 , only 37 female rats presented with glycemia between 120 and $300 \mathrm{mg} / \mathrm{dL}$ and were included in the STZ group; only 28 rats reached term pregnancy. In the control group, 45 female rats received citrate buffer during the neonatal period. All of the rats reached the reproductive phase and were mated. Of the 45 mated female rats, 37 were pregnant with glycemia less than to $119 \mathrm{mg} / \mathrm{dL}$ and were included in control group. On day 21 of pregnancy, 28 rats had reached term pregnancy.

\subsection{Glycemia during pregnancy}

In control rats, normoglycemia was confirmed with mean glucose values below $119 \mathrm{mg} / \mathrm{dL}$ (day 0, 7, 14 and 21 of pregnancy). In STZ rats, a significantly higher glycemia $(\mathrm{p}<0.05)$ was verified on days 0 and 14 of pregnancy compared to control rats (Table 1).

\subsection{Maternal weight gain during pregnancy}

Throughout pregnancy, an increase in body weight in STZ and control rats was observed. However, on days 0, 7, 14 and 21 of pregnancy, the STZ dams presented with lower body weight $(\mathrm{p}<0.05)$ and maternal weight gain (day 21 - 0) compared to control rats (Table 2).

\subsection{Fetal weight, placental weight and placental index}

There was no significant difference in fetal weight between STZ rats and control rats. STZ rats presented with higher placental weight and index $(\mathrm{p}<0.05)$ relative to control group (Table 3).

\subsection{Classification of fetal body weight}

The fetuses from the STZ group presented with a significant increase in the proportion of fetuses classified as small (SPA) and large (LPA) for pregnancy age, and a sig- nificant reduction in the proportion of APA (appropriate for pregnancy age) fetuses compared the from control group (Figure 1).

\subsection{Analysis of the frequency of external and skeletal anomalies}

Table 4 illustrates fetuses from STZ female rats that presented no significant difference in the rates of external anomalies compared to the control group. Fetuses from the STZ group presented with a higher number of abnormal sternebra and absent cervical nuclei $(\mathrm{p}<0.05)$.

\subsection{Ossification sites}

There was no significant difference ( $p>0.05)$ in the number of ossification sites in fetuses from STZ group in relation to the control group (Table 5).

\section{Discussion}

In the present study, it was verified that neonatally streptozotocin-induced diabetic rats presented glycemia superior than $120 \mathrm{mg} / \mathrm{dL}$ on day 0 of pregnancy, confirming the inclusion criterion for the diabetic group. On day 14 of pregnancy an increase in glycemic mean was also observed in this group, which was accompanied by glucose intolerance and insulin resistance (data submitted to publication - not shown in this paper) as demonstrated by the glucose and insulin tolerance tests, respectively, reproducing the clinical state of gestational diabetes that occurs at weeks 24-26 of human gestation [36,37]. The literature shows conflicting results about glycemia and insulin levels in the different models of mild diabetes induction. However, the experimental model that presented more convincing results (glycemia between 120 and $300 \mathrm{mg} / \mathrm{dL}$ ) was the induction performed during the neonatal period $[26,27,38,39]$.

Our results showed that STZ rats presented increased maternal weights since the beginning of pregnancy. There is a natural progressive increase in maternal weight during gestation due to fetal growth apart from adapta-

Table 1: Glycemic levels on days 0, 7, 14 and 21 of pregnancy in mildly diabetic (STZ) and non-diabetic (control) rats.

\section{Groups}

\begin{tabular}{lcc}
\hline & $\begin{array}{c}\text { Control } \\
(\mathbf{n = 2 8})\end{array}$ & $\begin{array}{c}\text { STZ } \\
(\mathbf{n}=\mathbf{2 8})\end{array}$ \\
\hline Maternal glycemia $(\mathbf{m g} / \mathbf{d L})$ & & $131.70 \pm 1.87^{*}$ \\
Day 0 & $105.00 \pm 1.81$ & $106.10 \pm 2.56$ \\
Day 7 & $102.80 \pm 2.36$ & $92.90 \pm 2.45^{*}$ \\
Day 14 & $83.10 \pm 1.45$ & $83.70 \pm 2.69$ \\
Day 21 & $85.30 \pm 1.92$ & \\
\hline
\end{tabular}

Data are reported as mean \pm standard error of mean (SEM)

${ }^{*} p<0.05$ - statistically significant difference compared to control group (Student-Newman-KeulsTest). 
Table 2: Body weight on days 0, 7, 14, 21 and maternal weight gain (day 21 - 0) in pregnant mildly diabetic (STZ) and nondiabetic (control) rats.

\begin{tabular}{|c|c|c|}
\hline & \multicolumn{2}{|c|}{ Groups } \\
\hline & $\begin{array}{l}\text { Control } \\
(n=28)\end{array}$ & $\begin{array}{c}\text { STZ } \\
(n=28)\end{array}$ \\
\hline Day 0 & $284.19 \pm 4.66$ & $260.71 \pm 7.99^{*}$ \\
\hline Day 7 & $305.29 \pm 5.09$ & $278.81 \pm 7.90^{*}$ \\
\hline Day 14 & $330.96 \pm 5.36$ & $303.26 \pm 8.71^{*}$ \\
\hline Day 21 & $407.22 \pm 6.43$ & $357.86 \pm 11.67^{*}$ \\
\hline Maternal weight gain (day 21-0) & $123.03 \pm 2.91$ & $97.81 \pm 4.91 *$ \\
\hline
\end{tabular}

Data are reported as mean \pm standard error of mean (SEM)

${ }^{*} p<0.05$ - statistically significant difference compared to control group (Student-Newman-KeulsTest).

tions of the maternal organism [40,41]. However, the weight gain of STZ rats during the pregnancy was lower compared to control group. The lower gain of maternal weight in the presence of mild diabetes may be related to STZ administration at neonatal period. There were early damages to the pancreatic $\beta$-cells, reducing insulin secretion which is considered major growth factor, contributing to impaired perinatal development and leading to consequences in the adult life of neonatally streptozotocin-induced diabetic rats, as also confirmed by Kim et al. (2006) [42]. These authors related the reduction of maternal weight gain to alterations in growth hormone $(\mathrm{GH})$ and insulin-like growth factor (IGF-1) in the neonatally streptozotocin-induced diabetic female rats.

Infants of diabetic or prediabetic women frequently have increased birth weight and length [43]. They have also been found to have enlarged islets of Langerhans and $\beta$-cells [44] and higher than normal concentrations of plasma insulin. Further, there is evidence that insulin injection into rats during pregnancy results in larger than normal fetuses. Experimental models of mild diabetes induction (glycemia between 120 and $300 \mathrm{mg} / \mathrm{dL}$ ) showed increased rates of macrosomic fetuses (LPA)
$[3,28,29]$. In contrast with these studies, our study revealed increased rates of fetuses classified as small for pregnancy age in mildly diabetic dams. Similarly, Kervran et al. (1978) [45] did not obtain macrosomic fetuses in the offspring of rats with mild hyperglycemia during pregnancy. The difference between the findings in clinical and experimental studies might be justified by the relatively short pregnancy time in the rat, the difference in the percentage of adipose tissue in rat fetuses $(1 \%)$ and human offspring (16\%), and the greater weight gain in the human species. Our findings corroborate results found by Aerts \& Van Assche (2006) [46] and Holemans et al. (2003) [47], which also observed fetuses with intrauterine growth restriction (IUGR) originated from mildly diabetic rats. An epidemiological relationship between low birth weight and impaired glucose tolerance in late life has been shown $[48,49]$ and evidence for both insulin resistance and impaired function of the pancreatic $\beta$-cell in adulthood has been presented [50-52]. The human fetuses classified as small for gestational age (SGA) fetus is hypoinsulinemic and hypoglycemic [53,54]. A glucose challenge in the uterus provokes only a small insulin secretory response [55], and this inability persists in the

Table 3: Fetal weight, placental weight and placental index in mildly diabetic (STZ) and non-diabetic (control) rats at term pregnancy.

Groups

\begin{tabular}{llc}
\hline & $\begin{array}{c}\text { Control } \\
(\mathbf{n = 2 8 )}\end{array}$ & $\begin{array}{c}\text { STZ } \\
\text { (n= 28) }\end{array}$ \\
\hline Fetal weight & $5.40 \pm 0.05$ & $5.34 \pm 0.09$ \\
Placental weight & $0.40 \pm 0.01$ & $0.46 \pm 0.01^{*}$ \\
Placental index & $0.08 \pm 0.00$ & $0.09 \pm 0.00^{*}$ \\
\hline
\end{tabular}

Data are reported as mean \pm standard error of mean (SEM)

${ }^{*} p<0.05$ - statistically significant difference compared to control group (Student-Newman-KeulsTest). 


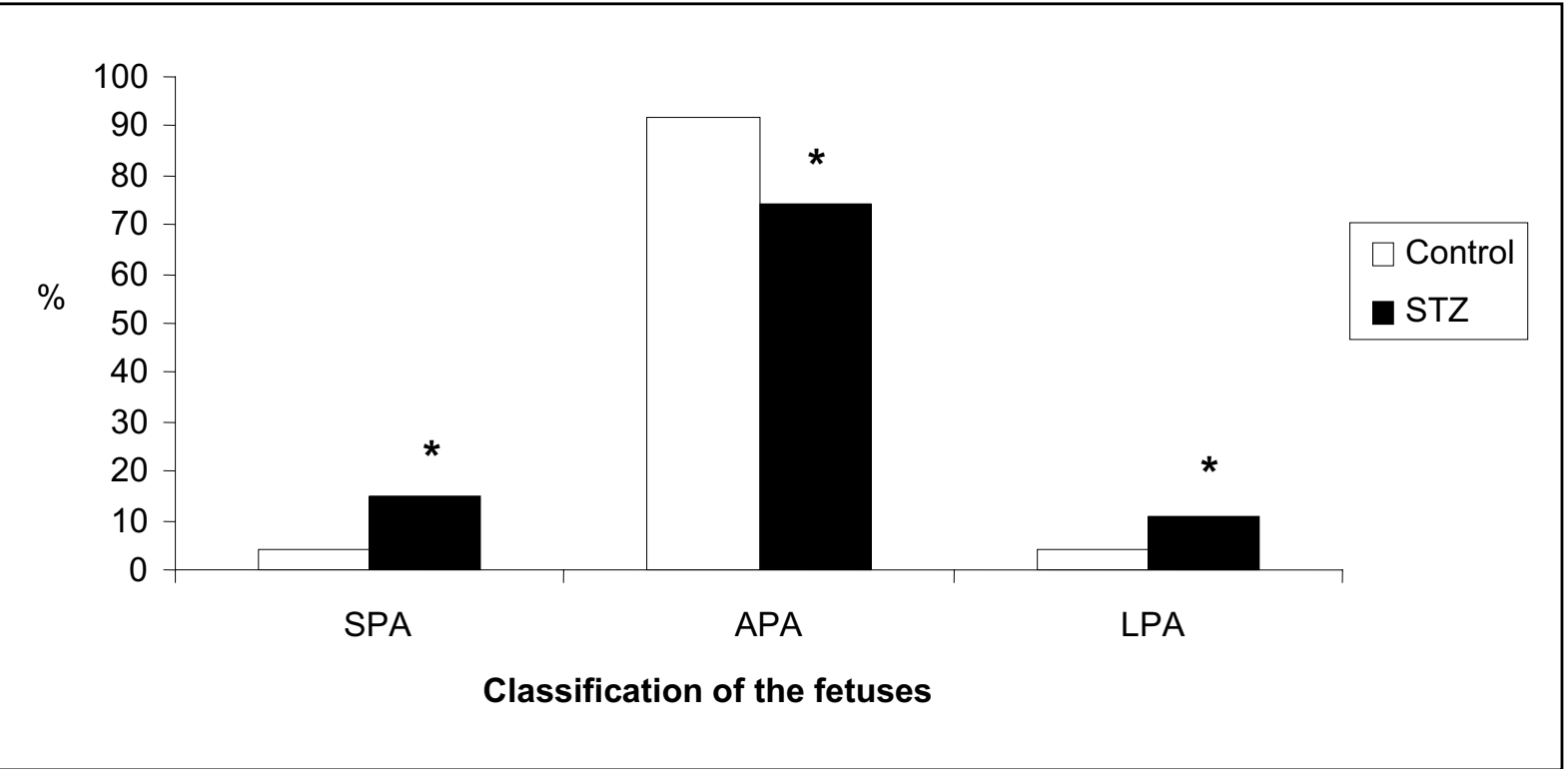

Figure 1 Proportion (\%) of fetuses classified as small (SPA), appropriate (APA) and large (LPA) for pregnancy age from mildly diabetic (STZ) and non-diabetic (control) rats at term pregnancy. ${ }^{*} p<0.05$ - statistically significant difference compared to control group (Chi Square Test).

neonate $[56,57]$. In the few cases which have been morphologically investigated, there is evidence of a reduced pancreatic $\beta$-cell mass [58]. This suggests reduced growth and impaired functional development of the insulin-producing $\beta$-cell in growth-retarded fetuses $[49,50]$. Fetal growth is a complex process that depends on the genotype and epigenotype of the fetus, maternal nutrition, the availability of nutrients and oxygen to the fetus, intrauterine insults, and a variety of growth factor and proteins of maternal, fetal and placental origin [59]. During the first

Table 4: Frequency of external and skeletal anomalies in fetuses from mildly diabetic (STZ) and non-diabetic (control) rats at term pregnancy.

\section{Groups}

\begin{tabular}{|c|c|c|}
\hline & $\begin{array}{l}\text { Control } \\
(n=15)\end{array}$ & $\begin{array}{c}\text { STZ } \\
(n=13)\end{array}$ \\
\hline $\begin{array}{l}\text { Number of fetuses examined for external } \\
\text { anomalies }\end{array}$ & 198 & 138 \\
\hline Number of fetuses with external anomalies & 0 & 0 \\
\hline $\begin{array}{l}\text { Number of fetuses examined for skeletal } \\
\text { anomalies }\end{array}$ & $81(100 \%)$ & $55(100 \%)$ \\
\hline Abnormal shaped sternebrae & $2 / 81(2 \%)$ & $5 / 55(9 \%)^{*}$ \\
\hline Extra ossification site of sternebrae & $0 / 81(0 \%)$ & $1 / 55(2 \%)$ \\
\hline Incomplete ossification of vertebrae & $1 / 81(1 \%)$ & $0 / 55(0 \%)$ \\
\hline Absent cervical nuclei & $50 / 81(62 \%)$ & $57 / 55(104 \%)^{*}$ \\
\hline Bipartite cervical nuclei & $3 / 81(4 \%)$ & $1 / 55(2 \%)$ \\
\hline $\begin{array}{l}\text { Incomplete ossification of cervical } \\
\text { nuclei }\end{array}$ & $5 / 81(6 \%)$ & $5 / 55(9 \%)$ \\
\hline
\end{tabular}

${ }^{*} p<0.05$ - statistically significant difference compared to control group (Chi Square Test). 
Table 5: Ossification sites in fetuses from mildly diabetic (STZ) and non-diabetic (control) rats at term pregnancy.

\begin{tabular}{lcc}
\hline & & Groups \\
& & $\begin{array}{c}\text { Control } \\
(\mathbf{n = 1 5})\end{array}$ \\
& & STZ \\
& & \\
\hline Sternebrae & $6.00 \pm 0.00$ & $6.01 \pm 0.05$ \\
Anterior phalange & $3.97 \pm 0.08$ & $3.97 \pm 0.27$ \\
Posterior phalange & $2.57 \pm 1.09$ & $2.42 \pm 1.08$ \\
Metacarpus & $4.00 \pm 0.00$ & $4.03 \pm 0.19$ \\
Metatarsus & $4.97 \pm 0.05$ & $4.75 \pm 0.33$ \\
Number of caudal vertebrae & $4.38 \pm 0.80$ & $4.29 \pm 0.89$ \\
Total number of ossification sites & 25.88 & 25.52 \\
\hline
\end{tabular}

$p>0.05$ - non statistically significant difference

trimester of pregnancy, embryonic growth might be controlled at the level of the individual organs by nutrient supply and by locally active growth factors. Later, fetal growth depends essentially upon materno-placental cooperation in delivering nutrients to the fetus. Fetal growth seems to be regulated by fetal insulin, insulin-like growth factor (IGF-1) and IGF-2, while growth hormone $(\mathrm{GH})$ has only a secondary hole to play [60]. During pregnancy placental growth hormone $(\mathrm{PGH})$ is the prime regulator of maternal serum IGF-1. Therefore the major hole of hormones in fetal growth is to mediate utilization of available substrate. The alterations in the maternal GH/ IGF axis may lead to permanent pathological fetal programming of the IGF axis [59], causing late consequences of poor fetal environment reflected in intrauterine growth restriction, as confirmed by our results.

It was observed in our study that the placentas of mildly diabetic rats had a higher weight, which might represent a compensatory mechanism to assure the maternal-fetal exchanges contributing to fetal development. This justifies the similar mean fetal weights between the two groups (STZ and control). The increased weight of the placentas also contributed to increased placental index in the diabetic group. However, the increased placental weight/index was not enough to improve fetal development, as confirmed by increased rate of fetuses classified as small for gestational age.

Maternal diabetes during pregnancy is known to increase the risk of congenital malformation in offspring. The malformations associated with diabetic pregnancy affect many major organ systems, such as the central nervous, cardiovascular, gastrointestinal, urogenital and musculoskeletal systems $[21,61]$. The incidence of congenital malformations in diabetic pregnancies remains two-to six-fold higher than in non-diabetic pregnancies $[8,18,19]$. Although clinical studies have indicated that the risk for congenital malformations is dependent on blood glucose levels in early pregnancy, recent studies show that even in diabetic pregnant women with near optimal maternal glycemic control (HbA1c < 7\%), the incidence of congenital malformations is still high $[8,62]$.

In this investigation was verified that the rates analysis of external anomalies of the fetuses from mild diabetic rats presented no significant abnormalities related to mild maternal diabetes. It was observed that fetuses from neonatally streptozotocin-induced mild diabetic rat presented an increased frequency of abnormal sternebra and absent cervical nuclei. However, these skeletal abnormalities are not considered to be major anomalies. In other words, the alterations caused by mild diabetes were not sufficient to cause the emergence of skeletal anomalies. The number of ossification sites among the experimental groups showed that there was not somatic immaturity in the development of the fetuses of female rats with mild diabetes, showing that the glycemic intensity did not influence the studied variable. In conclusion, mild diabetes caused alterations in fetal development characterized by intrauterine growth restriction, which was evidenced by the increase of the proportions of fetuses classified as small for pregnancy age. This glycemic intensity led no major congenital defects in the fetuses of streptozotocininduced diabetic rats, thus it was associated no teratogenic effect in these fetuses.

Competing interests

The authors declare that they have no competing interests.

\section{Acknowledgements}

The authors are grateful to Ana Paula Machado Spada, a post-graduation from Research Laboratory of Gynecology and Obstetrics, for her technical assistance and to the Research Support Center (RSC) of the Botucatu Medical School,

Univ Estadual Paulista (UNESP) for its valuable contribution in study design and statistical analysis. Financial support was provided by a fellowship from Fundação de Amparo à Pesquisa do Estado de São Paulo (FAPESP), at Isabela Lovizutto lessi (Grant/Process Number 07/08708-1), and financial support (Grant/ 
Process Number 06/06056-4) coordinated by Dr Débora Damasceno. There is no conflict of interest.

\section{Authors' contributions}

ILI participated in the acquisition, analysis and interpretation of data and helped to draft the manuscript. DCD conceived the study, participated in its design, coordination, analysis and interpretation of data and helped to draft the manuscript. $A B$ and YKS participated in the acquisition, analysis and interpretation of data and helped to draft the manuscript. KNT and MVCR helped to draft the manuscript. All the authors read and approved the final manuscript.

\section{Author Details}

1Botucatu Medical School, UNESP - Univ Estadual Paulista, Department of Gynecology and Obstetrics, Laboratory of Experimental Research in Gynecology and Obstetrics, São Paulo State, Brazil and 2Weill Cornell Medical College, New York, USA

Received: 8 February 2010 Accepted: 8 June 2010

Published: 8 June 2010

\section{References}

1. Rolo AP, Palmeira CM: Diabetes and mitochondrial function: Role of hyperglycemia and oxidative stress. Toxicol Appl Pharmacol 2006, 212(2):167-178

2. Metzger BE: The hyperglycemia and adverse pregnancy outcome (HAPO) study. International Journal Gynecology Obstetrics 2002, 78:69-77.

3. Merzouk H, Bouchenak M, Loukidi B, Madani S, Prost J, Belleville J: Fetal macrosomia related to maternal poorly controlles type 1 diabetes strongly impairs serum lipoprotein concentrations and composition. Journal Clinical Pathology 2000, 53:917-923.

4. Eriksson UJ: Congenital anomalies in diabetic pregnancy. Seminars in Fetal \& Neonatal Medicine 2008:1-9

5. Reece AE, Homko CJ: Pregnancy Care and the Prevention of Fetal Malformations in the Pregnancy Complicated by Diabetes. Clinical Obstetrics and Gynecology 2007, 50(4):990-997.

6. Ray JG, O'Brien TE, Chan WS: Preconception care and the risk of congenital anomalies in the offspring of women with diabetes mellitus: a meta-analysis. QJM 2001, 94:435-444.

7. Platt MJ, Stanisstreet M, Casson IF, et al:: St Vincent's declaration 10 years on: outcomes of diabetic pregnancies. Diabet Med 2002, 19:216-220.

8. Evers IM, de Valk HW, Visser GH: Risk of complications of pregnancy in women with type 1 diabetes: nationwide prospective study in the Netherlands. Br Med J 2004, 328:915-924.

9. Verheijen EC, Critchley JA, Whitelaw DC, Tuffnell DJ: Outcomes of pregnancies in women with pre-existing type 1 or type 2 diabetes, in an ethnically mixed population. Br J Obstet Gynaecol 2005, 112:1500-1503.

10. Schaefer-Graf UM, Buchanan TA, Xiang A, Songster G, Montoro M, Kjos SL: Patterns of congenital anomalies and relationship to initial maternal fasting glucose levels in pregnancies complicated by type 2 and gestational diabetes. Am J Obstet Gynecol 2000, 182:313-320.

11. Brydon P, Smith T, Proffitt M, Gee H, Holder R, Dunne F: Pregnancy outcome in women with type 2 diabetes mellitus needs to be addressed. Int J Clin Pract 2000, 54:418-419.

12. Dunne F, Brydon P, Smith K, Gee H: Pregnancy in women with Type 2 diabetes: 12 years outcome data 1990-2002. Diabet Med 2003, 20:734-738.

13. Garcia-Patterson A, Erdozain L, Ginovart G, et al.: In human gestational diabetes mellitus congenital malformations are related to prepregnancy body mass index and to severity of diabetes. Diabetologia 2004, 47:509-514.

14. Kucera J: Rate and type of congenital anomalies among offspring of diabetic women. J Reprod Med 1971, 7:61-70.

15. Towner D, Kjos S, Leung B, et al: Congenital malformations in pregnancies complicated by NIDDM. Diabetes Care 1995, 18:1446-1451.

16. Von Kries R, Kimmerle R, Schmidt JE, Hachmeister A, Bohm O, Wolf HG: Pregnancy outcomes in mothers with pregestational diabetes: a populationbased study in North Rhine (Germany) from 1988 to 1993. Eur J Pediatr 1997, 156:963-967.
17. Aberg A, Westbom L, Kallen B: Congenital malformations among infants whose mothers had gestational diabetes or preexisting diabetes. Early Hum Dev 2001, 61:85-95.

18. Hawthorne G, Robson S, Ryall EA, Sen D, Roberts SH, Ward Platt MP: Prospective population based survey of outcome of pregnancy in diabetic women: results of the Northern Diabetic Pregnancy Audit, 1994. Br Med J 1997, 315:279-281.

19. Casson IF, Clarke CA, Howard CV, et al:: Outcomes of pregnancy in insulin dependent diabetic women: results of a five year population cohort study. Br Med J 1997, 315:275-278.

20. Martínez-Frias ML: Epidemiological analysis of outcomes of pregnancy in diabetic mothers: identification of the most characteristic and most frequent congenital anomalies. Am J Med Genet 1994, 51:108-13.

21. Mills JL: Malformations in infants of diabetic mothers. Teratology 1982, 25:385-94.

22. Lopez-Soldado I, Herrera E: Different diabetogenic response to moderat doses of streptozotocin in pregnant rats, and its long-term consequences in the offspring. Exp Diabesity Res 2003, 4:107-118.

23. Damasceno DC, Volpato GT, Calderon IMP, et al.: Oxidative stress and diabetes in pregnant rats. Anim Reprod Sci 2002:235-244.

24. Eriksson UJ, Cederberg J, Wentzel P: Congenital malformations in offspring of diabetic mothers--animal and human studies. Rev Endocr Metab Disord 2003, 4(1):79-93.

25. Souza MSS, Lima PHO, Sinzato YK, Rudge MVC, Pereira OCM, Damasceno DC: Effects of cigarette smoke expose on pregnancy outcome of diabetic rats and on their offspring. Reproductive Bio Medicine Online 2009, 18(4):562-567.

26. Portha B, Levacher C, Picon L, Rosselin G: Diabetogenic effect of streptozotocinin on the rat during the perinatal period. Diabetes 1974, 23(11):888-895.

27. Tsuji K, Taminato T, Usami M, Ishida H, Kitano N, Fukumoto H, Koh G, Kurose $T$, Yamada Y, Yano H, et al:: Characteristic features of insulin secretion in the streptozotocin-induced NIDDM rat model. Metabolism 1988, 37:1040-1044

28. Merzouk H, Madane S, Boualga A, Prost J, Bouchenak M, Belleville J: Agerelated changes in cholesterol metabolism in macrosomic offspring of rats with streptozotocin-induced diabetes. J Lipid Res 2001, 42:1152-1159.

29. Merzouk H, Madani S, Hichami A, Prost J, Moutairou K, Belleville J, et al: Impaired lipoprotein metabolism in obese offspring of streptozotocininduced diabetic rats. Lipids 2002, 37(8):773-781.

30. Soulimane-Mokhtari NA, Guermouche B, Yessoufou A, Saker M, Moutairou K, Hichami A, Merzouk H, Khan NA: Modulation of lipid metabolism by $n-$ 3 polyunsaturated fatty acids in gestational diabetic rats and their macrosomic offspring. Clin Sci 2005, 109:287-295.

31. Merzouk H, Kahn NA: Implication of lipids in macrosomia of diabetic pregnancy: can $n-3$ polynsaturated fatty acids exert beneficial effects? Clin Sci 2003, 105:519-529.

32. Staples RE, Schnell VL: Refinements in rapid clearing technic in the $\mathrm{KOH}$ alizarin red S method for fetal bone. Stain Technol 1964, 39:61-63.

33. Aliverti V, Bonanomi $L$, Giavini E, et al:: The extent of fetal ossification as an index of delayed development in teratogenic studies on the rats. Teratology 1979, 20:237-242.

34. Vieira S: Estatística Experimental. Ed Atlas SA São Paulo 1999:313.

35. Zar JH: Biostatistical analysis. New Jersey: Pretence Hall; 1999.

36. Diamant $Y Z$, Metzger BE, Freikel N, Shafir E: Placental lipid and glycogen content in human and experimental diabetes mellitus. Am J Obstet Gynecol 1982, 144:5-11.

37. Desoye G, Hauguel-de Mouzon S: The human placenta in gestational diabetes mellitus. The insulin and cytokine network. Diabetes Care 2007, 30:120-126.

38. Bonner-Weir S, Trent DF, Honey RN, Weir GC: Responses of neonatal rat islets to streptozotocin. Diabetes 1981, 30:64-69.

39. Portha B, Kergoat M: Dynamics of glucose-induced insulin release during the spontaneous remission of streptozotocin diabetes induced in the newborn rat. Diabetes 1985, 34(6):574-579.

40. Rudge MVC, Borges VTM, Calderon IMP: Adaptação do organismo materno à gravidez. In Obstetrícia básica Edited by: Neme B. São Paulo: Sarvier; 2000:42-51.

41. Volpato GT, Damasceno DC, Campos KE, Rocha R, Rudge MVC, Calderon IMP: Avaliação do efeito do exercício físico no metabolismo de ratas diabéticas prenhes. Rev Bras Med Esporte 2006, 12:229-233. 
42. Kim E, Sohn S, Lee M, Jung J, Kineman RD, Park S: Differential responses of the growth hormone axis in two rat models of streptozotocininduced insulinopenic diabetes. J Endocrinol 2006, 188:263-270.

43. Farquhar JW: The child of the diabetic woman. Arch Dis Child 1959, 34:76-96.

44. Becerra JE, Khoury MJ, Cordero JF, Erickson JD: Diabetes mellitus during pregnancy and the risks for specific birth defects: a population-based case-control study. Pediatrics 1990, 851:1-9.

45. Kervran A, Guillaume M, Jost A: The endocrine pancreas of the fetus from diabetics pregnant rats. Diabetologia 1978, 15:387-393.

46. Aerts $L$, Van Assche FA: Animal evidence for the transgenerational development of diabetes mellitus. Int J Biochem Cell Biol 2006, 38:894-903.

47. Holemans K, Aerts L, Van Assche FA: Fetal growth restriction and consequences for the offspring in animal models. I Soc Gynecol Investg 2003, 10:392-399.

48. Hales CN, Barker DJ, Clark PM, Cox LJ, Fall C, Osmond C, Winter PD: Fetal and infant growth and impaired glucose tolerance at age 64 . BrMed 1991, 303:1019-1022.

49. McKeigue PM, Lithell HO, Leon DA: Glucose tolerance and resistance to insulin-stimulated glucose uptake in men aged 70 years in relation to size at birth. Diabetologia 1998, 41:1133-1138.

50. Robinson S, Walton RJ, Clark PM, Barker DJ, Hales CN, Osmond C: The relation of fetal growth to plasma glucose in young men. Diabetologia 1992, 35:444-446.

51. Cook JT, Levy JC, Page RC, Shaw JA, Hattersley AT, Turner RC: Association of low birth weight with $b$ cell function in the adult first-degree relatives of non-insulin dependent subjects. Br Med $J 1993$, 306:302-306.

52. Phillips DI, Barker DJ, Hales CN, Hirst S, Osmond C: Thinness at birth an insulin resistance in adult life. Diabetologia 1994, 37:150-154.

53. Economides DL, Proudler A, Nicolaides KH: Plasma insulin in appropriate- and small-for-gestacional-age fetuses. Am J Obstet Gynecol 1989, 160:1091-1094.

54. Hubinont C, Nicolini U, Fisk NM, Tannirandorn Y, Rodeck CH: Endocrine pancreatic function in growth-retarded fetuses. Obstet Gyneco/ 1991, 77:541-544.

55. Nicolini U, Hubinont C, Santolaya J, Fisk NM, Rodeck CH: Effects of fetal intravenous glucose challenge in normal and growth-retarded fetuses. Horm Metab Res 1990, 22:426-430.

56. Colle E, Shiff D, Andrew G, Bauer CB, Fitzhardinge P: Insulin responses during catch-up growth of infants who were small for gestacional age. Pediatrics 1976, 57:363-371.

57. Salle B, Ruitton-Uglienco A: Glucose disappearance rate, insulin response and growth hormone response in the small for gestacional age and premature infant of very low birth weight. Biol Neonate 1976, 29:1-17.

58. Van Assche FA, De Prins F, Aerts L, Verjans M: The endocrine pancreas in small-for-dates infants. Br J Obstet Gynaecol 1977, 84:751-753.

59. Alsat E, Marcotty C, Gabriel R, Igout A, Frankenne F, Hennen G, Evian-Brion $D$ : Molecular approach to intrauterine growth retardation: An overview of recent data. Reprod Fertil 1995, 7:1457-1464.

60. Setia S, Sridhar MG: Changes in GH/IGF-1 axis in intrauterine growth retardation: consequences of fetal programming? Horm Metab Res 2009, 41(11):791-198.

61. Kouseff BG: Diabetic embryopathy. Curr Opin Pediatr 1999, 111:348-352

62. Suhonen L, Hiilesmaa V, Teramo K: Glycaemic control during early pregnancy and fetal malformations in women with type 1 diabetes mellitus. Diabetologia 2000, 431:79-82.

doi: $10.1186 / 1758-5996-2-37$

Cite this article as: lessi et al., Evaluation of neonatally-induced mild diabetes in rats: Maternal and fetal repercussions Diabetology \& Metabolic Syndrome 2010, 2:37

\section{Submit your next manuscript to BioMed Central} and take full advantage of:

- Convenient online submission

- Thorough peer review

- No space constraints or color figure charges

- Immediate publication on acceptance

- Inclusion in PubMed, CAS, Scopus and Google Scholar

- Research which is freely available for redistribution 